\title{
e-interview
}

\section{Ian G. McKeith}

Ian McKeith is Professor of Old Age Psychiatry, Institute for Ageing and Health, University of Newcastle upon Tyne. He is Visiting Researcher at National Institute of Mental Health, Bethesda 1986 (Clinical Neurosciences Division). His special interest is clinical research in the field of dementia, particularly Lewy body disease He trained in Newcastle upon Tyne.

If you were not a psychiatrist, what would you do?

Something that involved sailing boats - a yacht skipper or sailing instructor maybe. Preferably in a warm climate.

What has been the greatest impact of your profession on you personally? Hearing the experiences of patients and those close to them has taught me a lot. And my profession has allowed me to make an international circle of colleagues and friends with similar ideas and interests. Both are privileges.

\section{Do you feel stigmatised by your profession?}

Briefly as a trainee but only with colleagues in other specialties. Never in the outside world.

Who was your most influential trainer, and why?

It is hard to single out only one. A great number of people have helped me. Garry Blessed (psychogeriatrician) taught me about multi-disciplinary teamwork before it was widely practised. Elaine Perry (neurochemist) and Robert Perry (neuropathologist) introduced me to research methodology and made me realise the importance of laboratory scientists and clinicians working together. They also painstakingly corrected my early attempts at writing papers. Willie Barker (neuropsychiatrist) continues to try to teach me to play chess (20 years and little progress).

Which book/text has influenced you most?

The one I read most recently!

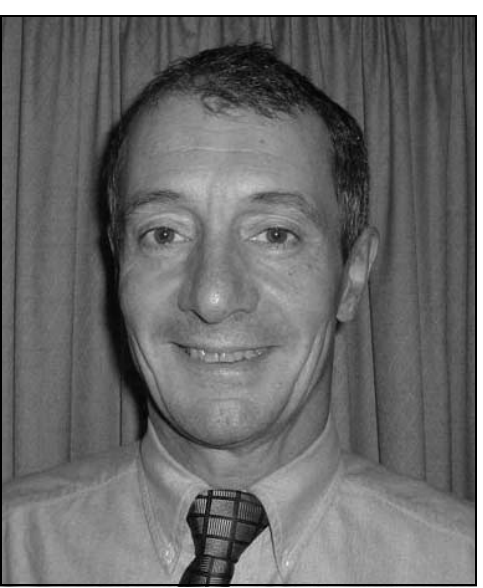

What research publication has had the greatest influence on your work? Probably Kendell's classic papers on the nature of affective disorders. They got me interested in issues of diagnosis and classification

What part of your work gives you the most satisfaction?

Seeing patients and carers and being able to offer them some help with what are often very chronic and burdensome illnesses. Spotting talented new individuals coming into old age psychiatry and trying to offer them the kind of support and encouragement that I have received.

\section{What do you least enjoy?}

The bureaucracy, which seems to mistrust our motives for doing what we do. Too many sticks, not enough carrots.

What is the most promising opportunity facing the profession?

Translating new research findings into clinical practice must be the answer to this. But it so often happens at a snail's pace. Doctors need to feel confident of professional and public support if they are to be creative and adopt new practices.

What is the greatest threat?

Over-regulation and governance. Of course we have to be open to scrutiny and accountable for all that we do. I have always been very careful about that, especially in work involving the use of post-mortem tissue. But the latest wave of directives, many from the EU, will possibly make most clinical research unsustainable. No one will benefit from that.

Do you think psychiatry is brainless or mindless?

Neither. Or both. It depends on your point of view. I've never thought that it was a useful question.

How would you entice more medical students into the profession?

Let them see as many patients as possible. Home visits are particularly good. If students are at all interested in psychiatry, they will be tempted to come back for more. The same cannot generally be said of even the best lectures or seminars.

What is the most important advice you could offer to a new trainee?

First find a good boss. Endear yourself to his/her secretary who will hopefully then train you as she has trained them. This advice is decidedly not tongue-in-cheek, and is endorsed by Mrs Maureen Middlemist, my secretary/PA for the past 11 years and co-trainer of a whole generation of old age psychiatrists.

How would you improve clinical psychiatric training?

As a generalisation, I think psychiatrists would benefit from more training in related specialties. I would have liked some formal training in neurology and neuropathology. Maybe it is not too late! Training should not end with CCSTstatus or consultancy.

What single area of psychiatric research should be given priority?

The question holds the key to our problem. We are accustomed in the UK to competing with one another for a share of a pitifully inadequate research funding pot. We should instead be collectively lobbying MPs and the public to increase the total amount of money spent on medical research so that all internationally competitive proposals can be supported as opposed to less than $50 \%$ at present. 